\title{
MEMORIES OF FARAWAY VISITORS TO SOUTHEAST ASIA: THE 'PORTUGUESE FORT' IN AMURANG
}

\author{
Maria Johanna Schouten ${ }^{1}$
}

Introduction

Anthropology cannot exist without history. This standpoint, which caused a stir in the anthropological world when formulated by Evans-Pritchard (1963) two generations ago, is widely accepted nowadays. It is generally recognized that the inclusion of a historical dimension and a consciousness of the change which takes place in societies are valuable and even necessary tools for the craft of anthropology. Reflectiveness, a fundamental requirement when handling the history of societies or groups, implies working with a couple of questions: What exactly is the history we are referring to? Which kind of history? Whose history? Which versions and interpretations of history? In matters related to colonialism, and in a broader sense of any situation including a flagrant inequality of power, a diversity of interpretations of the past is to be expected. Among the many factors which might influence the discourse, one which looms large in the study of colonialism and post-colonialism is the background of the spokespersons: did they or their parents belong to the category of subordinates or, on the contrary, of the oppressors? However, as the relationship between societal position and a version of the reality is not straightforward, seemingly incongruous or even awkward situations can arise.

One of these apparent anomalies is the nostalgia sometimes displayed by formerly subordinated people or groups when referring to colonial times, or certain aspects of those days. This clashes with the disapproval, current in academia and beyond, of relations of supremacy or feelings of superiority of the West vis-à-vis other societies. In particular it clashes with the expectation that the condemnation of colonialism should be a matter-of-course among the descendants of those formerly oppressed. Such paradoxical situations are narrowly related with the dissimilarities in the construction of knowledge: the facts fostered by people can be distinctly at variance with the facts based on scientific evidence. However, this distinction between what anthropologists usually label emics and etics is not absolute and in practice the

\footnotetext{
${ }^{1}$ Universidade da Beira Interior and CICS.NOVA.UMinho, Portugal.
} 
approaches can be intertwined. More than once, assertions based on non-scientific knowledge have been garnished with apparently scientific data. On the other hand, people could lend their own meaning to reality, a meaning not in accordance with the cool, or, for that matter, scientifically demonstrable, evidence. When applied to interpretations of the past, the observations by Nora come to mind: in contrast to history, as a scholarly discipline, 'memory is life, in constant change' (Nora, 1989: 8).

Colonialism and its legacy is one of those issues subject to diverse interpretations and to re-interpretation. Memories are malleable and adaptable. As Young (2003: 7) has stated, an important way of thinking and practice in our days: 'Postcolonialism is about a changing world', and these changes also include transformation of ideas, both among westerners and among the people of formerly subaltern groups. This means also that certain circumstances can lead to a nostalgia for colonial times (Bissell, 2005) or a re-writing of the past (Pires, 2014). The apparent absence, among some formerly subordinated people, of the assumption of the role of a victim, let alone vindictiveness, might be puzzling. If they present us with a truth which can be easily exposed as a distortion of so-called evidence-based reality, it becomes more complicated still. But their truth should not be discarded. For anthropologists, such thoughts and attitudes are a very fruitful area to examine in greater detail, and this attention in itself can facilitate the understanding of other people's living world.

Material objects and features of the built environment are important tools in constructing or reconstructing ideas about the past in formerly colonized areas. Regarding areas once dominated by the Portuguese, worth citing are the studies by Sarmento $(2011,2012)$ and by Pires (2012) who, in a postcolonialist approach, consider the way how edifices and areas have become heritage sites, with new stories attached to them.

It is against this background that in this article we shall address the former Portuguese and Spanish supremacy in parts of the Southeast Asian archipelago, and consider the lasting influence of these episodes. Central to the text is the architectural legacy of European powers, in particular the remains of a fortification, commonly known as the 'Portuguese fort', in the town of Amurang in the island of Sulawesi, Indonesia. The objective is to make an assessment, albeit preliminary, of the significance of this fort to the population, in the context of a process which seems to be a recycling of certain episodes in colonial history. 
The essay commences with some data about fortifications and their functions in the context of early European presence in eastern Indonesia. Having set the scene, we zoom in on the town of Amurang and its topography, paying special attention to the heart of the town, which is the market-place, located next to the fort. This building will be described in detail in the subsequent section, which will also include some results of archaeological research. Closely connected to these data are the stories and explanations current among the local population about the origin of the edifice, its former functions and the presumed lost or hidden parts of its structure. In all these stories, a major role is attributed to the 'Portuguese', and therefore on the final pages the ambivalent meaning of 'Portuguese' in this particular Southeast Asian context, and in postcolonial times, will be considered.

The text is based on anthropological and historical explorations. Data were gathered over several years, but chiefly in 2016, through observation, consultation of published and unpublished written sources, and in interviews with experts, government officials and the local population.

Figure 1: Map of Indonesia, indicating Minahasa in northern Sulawesi.

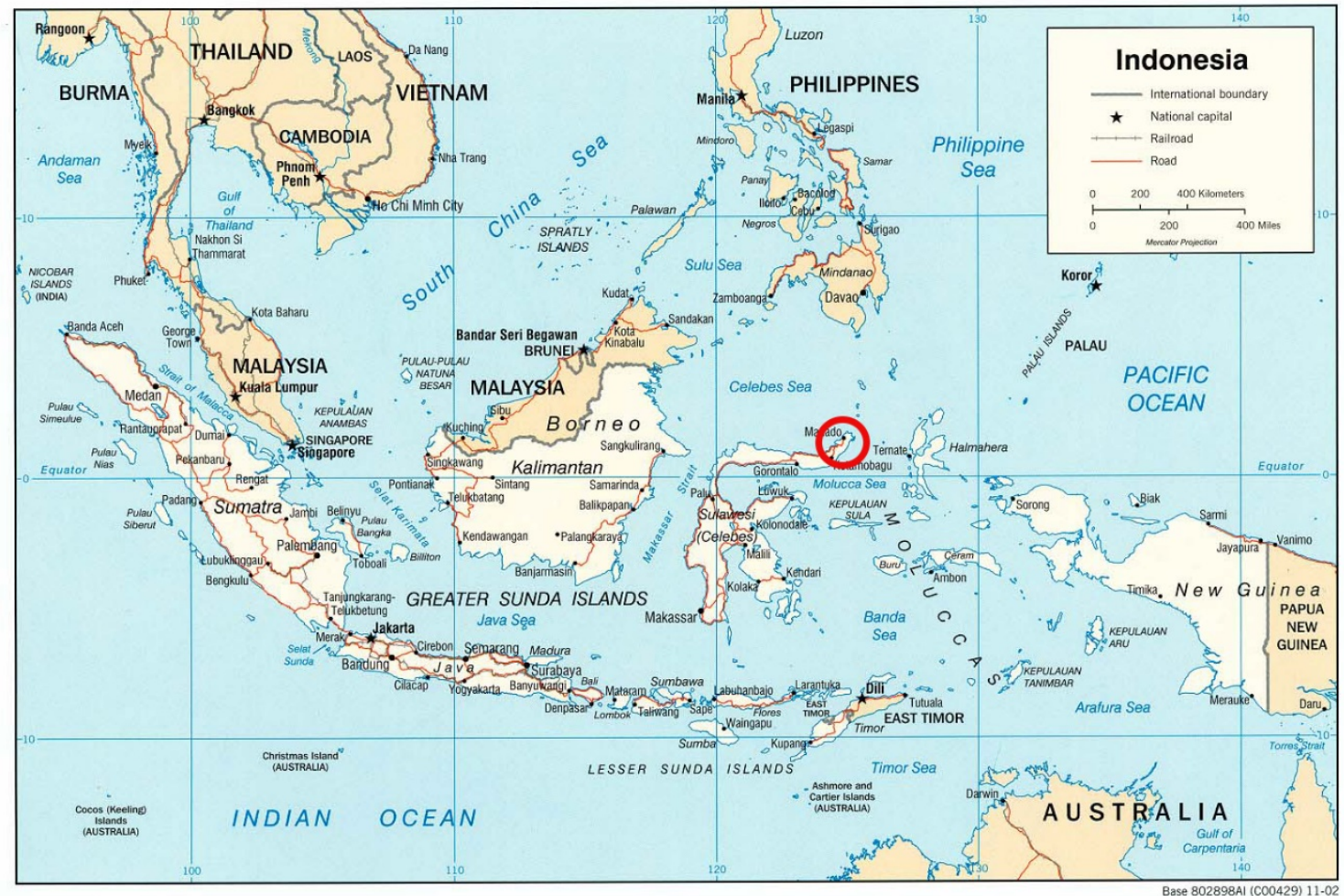

Source: Beccaloni and Purser, 2019. 
Forts in Eastern Indonesia: encounters between East and West

The various forts whose vestiges nowadays still dot the coasts of Southeast Asia had, in times past, an important symbolic and instrumental value. Built by political entities or trading organizations, as well as by religious congregations and private groups and persons, forts provided safe trading places and lodgings for outsiders, and also contributed to the defence of people and land.

Trade and greed were the main reasons behind the European voyages to Eastern Indonesia, since this was the zone where nutmeg and cloves were produced, two of the most coveted commodities in the contemporaneous world economy. The Portuguese and later the Spanish installed themselves on some spice islands, Ternate the most prominent of them, and in the seventeenth century they were followed by the Dutch. The strongholds they erected at strategic coastal locations were usually equipped with cannon and other sorts of weapons, primarily to ward off rival powers, but also a handy defence against pirates (Warren, 1981; Schouten, 1998: 49; Lapian, 1987).

These forts and their immediate surroundings accommodated small communities of military and other personnel of the western powers, often with their families. Many of their dwellers hailed directly or through their forebears from Europe, elsewhere in Asia and sometimes Africa. They had fallen into the lap of the European seafaring powers as soldiers, interpreters, or ship's boys, and, in the case of women, often through marital relationships. Others had established a special bond with the Europeans, for instance, through adoption, or had been taken as slaves (Schouten, 1999).

The interiors of the islands were a different world. The population lived in small tribal communities and practised simple agriculture, hunting, freshwater fishing, and gathering. Almost everywhere in the eastern islands, coast-dwellers and Asian and European visitors associated the 'mountain people', often called 'Alfurs', with violence and backwardness, and, although the natives were necessary to the supplies of commodities and foodstuff, in particular rice, they kept contact to a minimum. In fact, usually these contacts were indirect and relied on middlemen: native headmen or a resident of the fort endowed with particular skills, such as knowledge of the local language(s). 
The region of Manado, or Minahasa, was the usual name for the north-eastern tip of Sulawesi. On account of its geographical location as well as its place in the maritime trade routes, it was often considered to be part of the realm of the Moluccas. It was not a spice-producing area, but its maritime and forest products were in great demand on the Asian market. The first important contact of this region with the Portuguese occurred in 1563. In that year, the Portuguese governor in Ternate sent a military expedition to the region of Manado, and the missionaries who accompanied it baptised 1,500 of its inhabitants. A second missionary visit, in 1568, is the last officially recorded Portuguese delegation to northern Sulawesi (Lach, 2008: 618-621 and note 654; Stokman, 1931: 527; Lapian, 2004: 8).

In contrast, the presence and influence of the Spanish, who arrived in the region some decades later, was considerably more intense ${ }^{2}$. With some frequency, Spanish ships loaded rice in the town of Manado or in the nearby ports of Kema and Amurang and at certain periods military personnel were posted in the region. Spanish missionaries preached the Gospel in both the coastal and the mountainous areas (Godée Molsbergen, 1928: 8-18). One sure signal of incipient Spanish ambitions was the initiation of the construction of a fortification in Manado in the 1620s (Godée Molsbergen, 1928: 14; Stokman, 1931: 537). In the 1640s, however, some violent actions perpetrated by the Castilians in the inland triggered an armed protest among the population.

In the meantime, the Dutch VOC (Vereenigde Oost-Indische Compagnie, United East India Company) was expanding its influence enormously in Eastern Indonesia and its ships regularly visited northern Sulawesi. In its efforts to seize the suzerainty, the VOC manipulated the resentment the Minahasans felt towards the Spanish. In the wake of these machinations the latter were forced to retreat to the south, where they held out for some time in Amurang, but were eventually, in 1660, expelled from this last 'hiding place' by VOC vessels (Van Aernsbergen, 1925: 25; Godée Molsbergen, 1928: 18).

In 1656, the Dutch began the construction of a fort in the town of Manado. The initial wooden palisade was soon after replaced by a stone structure, called Fort Amsterdam (Watuseke and Henley, 1994: 365; Godée Molsbergen, 1928: 15). This more dignified version of the fortification, completed in 1703 with a stone outer wall (Graafland, 1867: 14-15), became a major symbol of Dutch superiority in the Minahasa

\footnotetext{
${ }^{2}$ The Spanish had arrived in the Moluccas in the 1520 s and by 1571 had established their governmental centre for eastern Asia in Manila, erecting strongholds in several places, including Ternate and the island of Siau, to the north of Manado.
} 
region, which long remained unchallenged by other European powers ${ }^{3}$. The sovereignty of the VOC was transposed in 1800 to the colonial state of the Dutch East Indies, which exerted a harsh regime in Minahasa particularly in the nineteenth century (Schouten, 1998: 39-146), The independence of Indonesia shortly after the end of World War Two produced a very new and very different political context.

Amurang and environs

Figure 2: Aerial view of the town of Amurang. At the top, the west, is the estuary of the Rano i Apo River, 2017

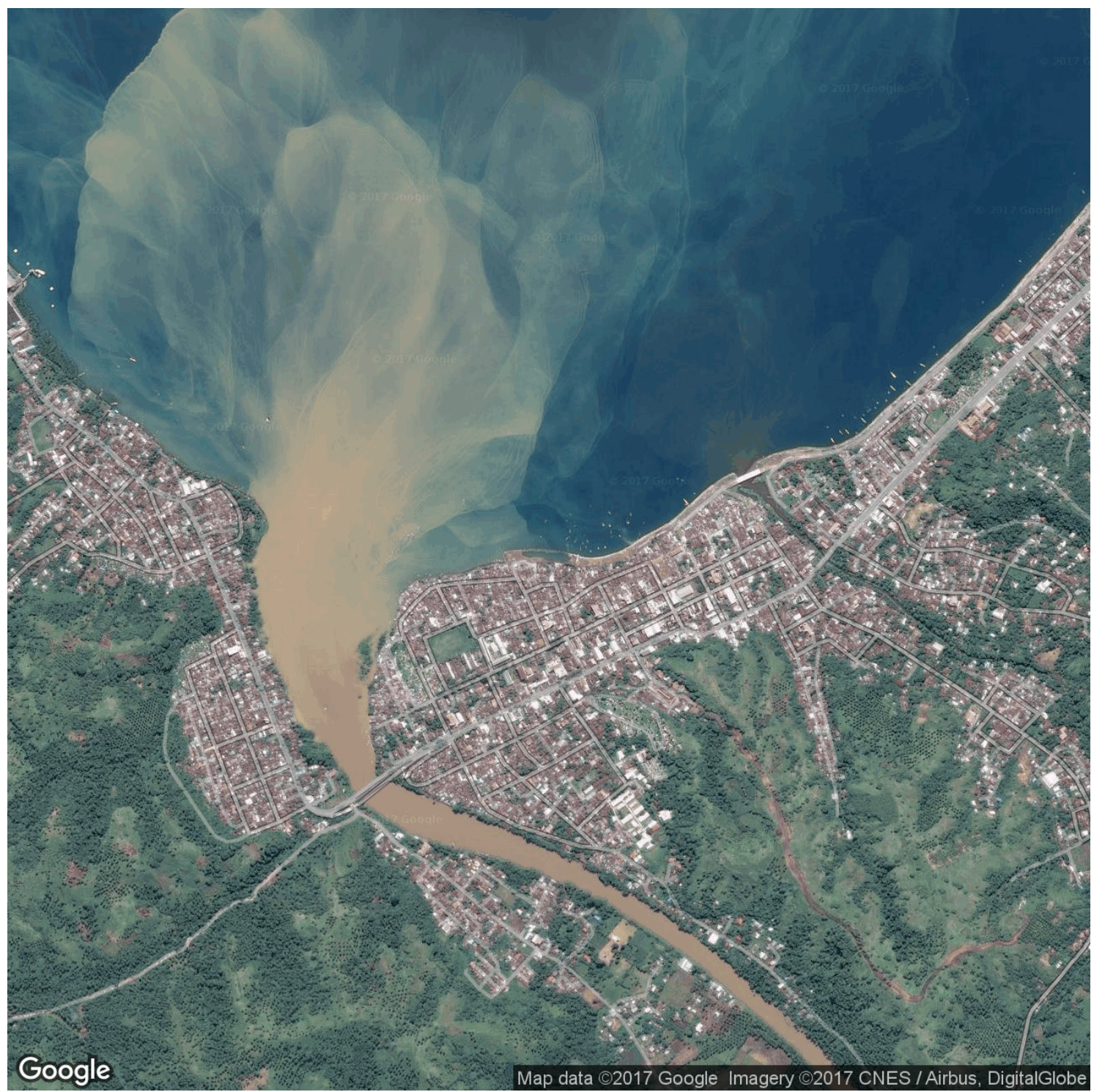

Source: Google

${ }^{3}$ Except for a short interregnum of the English, in the period of the Napoleonic Wars.

Iluminuras, Porto Alegre, v. 20, n. 50, p. 09-31, julho, 2019. 
The southern Minahasa town of Amurang, which had about 16,000 inhabitants in 2016, is located on a bay to the north of the Rano-i-Apo River, the 'river of the forebears', wide and imposing at its estuary and feared as a haunt of crocodiles ${ }^{4}$. The central part of the town, often named Uwuran, has been inhabited for many generations mostly by people with distant origins, in particular 'Borgo' or Eurasians, Chinese and Arabs - each in their own neighbourhood.

At the end of the twentieth century, the town centre was a densely built-up area which welcomed thousands of visitors every day, most of whom came to trade and to attend to personal business. The buildings of the administration, police and major services, a prison, churches and mosques, the market and shops, a variety of dwellings, the bus station were all closely clustered together - and amid all this lay the ruins of a fort, which would go unnoticed by anyone unaware of its existence.

However, in the past two or three decades, the layout of the town centre has undergone major changes. In the process of the administrative decentralization in Indonesia, in 2000 Amurang was made the capital of the newly created kabupaten (district) of South Minahasa. With the expansion of the jurisdictions and services which this upgraded status involved, most government services were installed in new buildings situated somewhat north of the town centre.

The bus terminal, formerly conveniently located next to the market-place, also had to move. Entry to the narrow street which leads to the market is now prohibited to all four-wheel vehicles, including the tiny version of the minibus known as a mikrolet. However, this has not really reduced the motorized traffic on this path, since marketgoers travelling by bus seldom walk the 700 or so metres between the new terminal and the market-place, but prefer to hire an ojek (motorbike taxi). This is the ubiquitous means of transport in contemporary Indonesia, and also provides a handy source of income for the (mostly young) unemployed.

Amurang's market has a wide regional function, and attracts traders and customers from near and far, not least from southern Minahasa, beyond the Rano-i-Apo River. The great diversity of fruits and vegetables on sale in the stalls lining the street lends the entrance area a colourful image. Plunging more deeply into the covered section of the market, all kinds of fish and meat are available, including the extraordinary ingredients of famous Minahasa culinary specialities. Common favourites

\footnotetext{
${ }^{4}$ About the estuary of the Rano I Apo in the nineteenth century, see De Clercq, 1870: 521-522.
} 
are bats, dogs and rats, but in Amurang and a handful of other 'extreme markets' (pasar ekstrim in Manado-Malay, the regional vernacular ${ }^{5}$ ), the meat of wild boars, monkeys and snakes is also on sale. This meat is coveted by Minahasans for its flavour but even more for the status which the serving of such dishes at a party or ceremony confers. The highest prestige, and hence the highest prices at the market, are fetched by the meat of the very rare and officially protected animals, unique to northern Sulawesi and some nearby areas of the Wallacea zone ${ }^{6}$. These include the anoa (dwarf buffalo) and the babirusa or deer-pig, whose male specimen makes a stunning impression with its four facial tusks. Another characteristic animal is the maleo bird, whose giant eggs are a top gastronomic treat among Minahasans. Not surprisingly, these eggs are keenly sought after by poachers, and so the maleo has joined the group of Sulawesi species under severe threat of extinction (Wallace, 1962: 203; Dekker and McGowan, 1995: 31-32).

Figure 3: Maleo

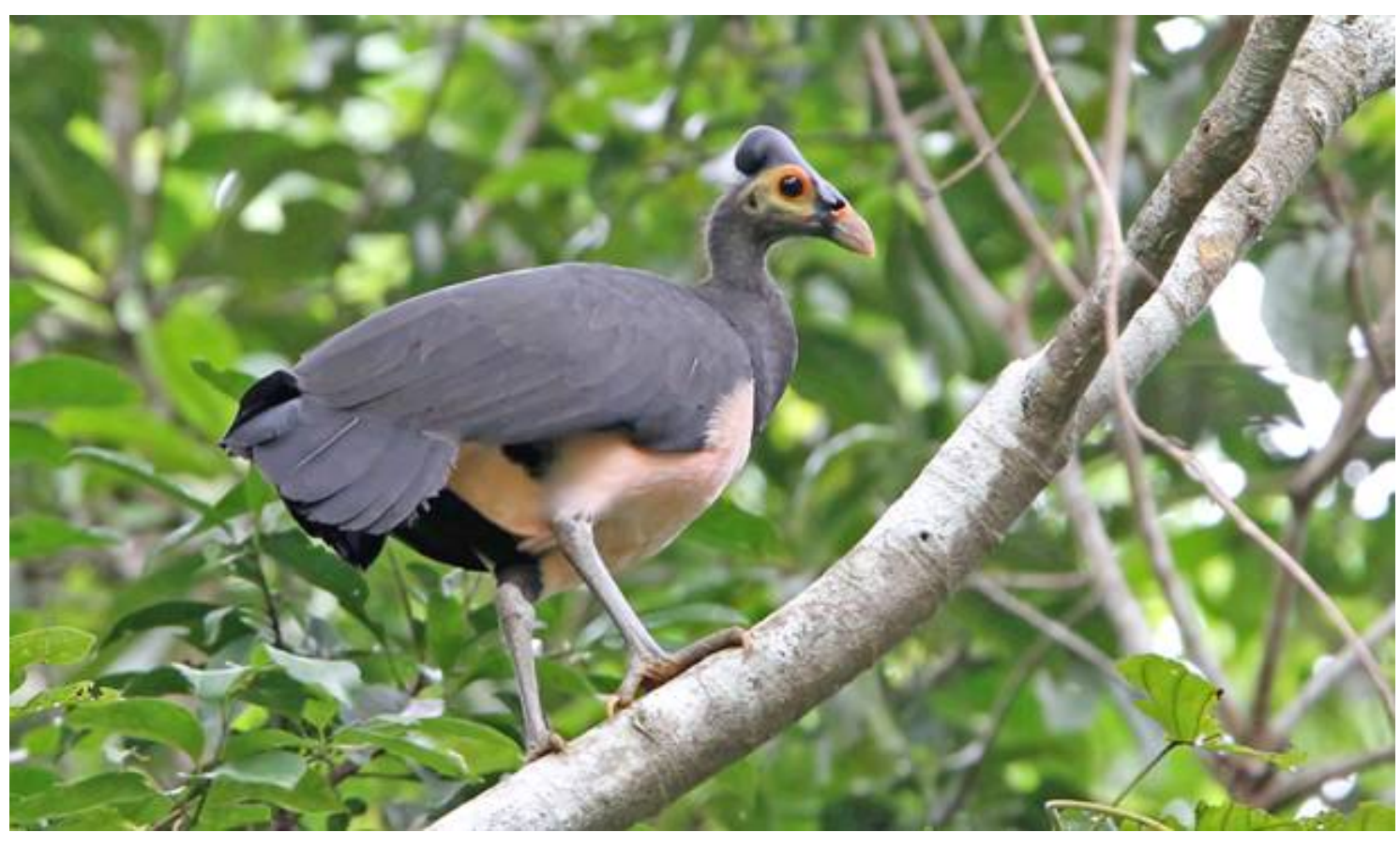

From the article 'Burung maleo' (2016), available at https://aumifaras.wordpress.com/2016/04/23/burung-maleo/

\footnotetext{
${ }^{5}$ Bahasa Indonesia, the official national language, is a standardized form of Malay. Throughout Indonesia, regional variations of Malay are used in informal contexts. Besides, hundreds of regional (Austronesian and Papuan) languages are spoken in the country.

${ }^{6}$ Wallacea (named after the naturalist Alfred Russel Wallace who in the nineteenth century did pathbreaking research in the archipelago) designs those islands in Indonesia that form the border region between the geological -biological zone of Asia and that of Australia. Wallacea includes Sulawesi and the Moluccas and is home to quite remarkable species of fauna.
} 
Figure 4: A maleo egg, normal size

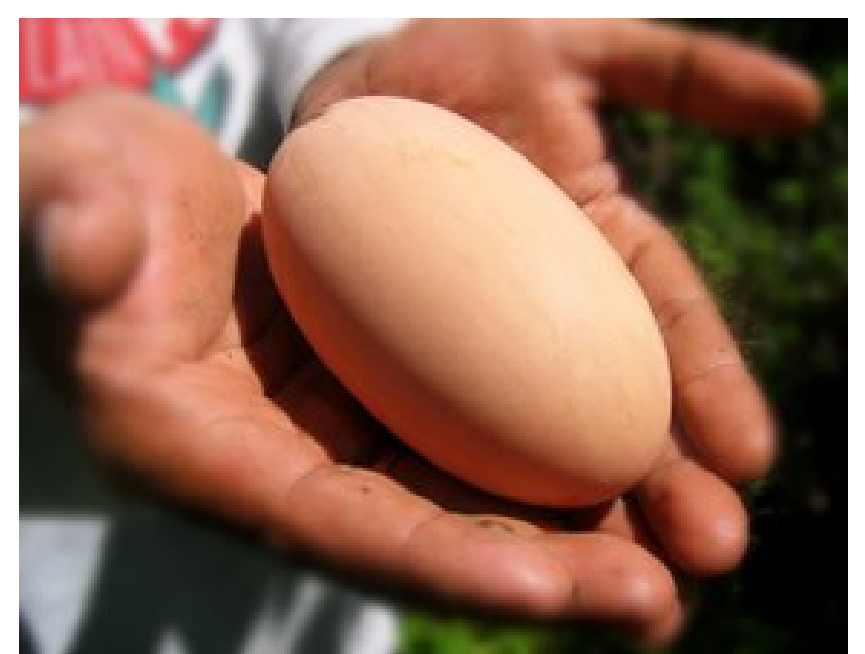

Source: www.apakabardunia.com/2011/02/unik-burung-maleo-sehabis-bertelur.html

During the morning hours, the Amurang market-place teems with people, animals dead and alive, the grunts and squawks of all sorts of living creatures, the blaring of loud music from the speakers, and trading and butchering. Through the narrow and crowded pathways between the market stalls, visitors move cautiously over a floor which is slippery with blood and slime, mixed with garbage.

The fort

This is the apparently chaotic environment which encircles the remains of the fort at Amurang, commonly called the "Portuguese fort". At the time of our first visit to the town, in 1981, a short observation of the fort left us with the impression of nothing more than a dilapidated stone wall, because the main part was hidden from view by all kinds of wooden structures propped up against it, market stalls and dwellings of fisherfolk predominating. 
Figure 5: Entrance to premises of the Amurang fort, showing the southern part of the wall, the gate, billboards and motorbike taxis, 2016

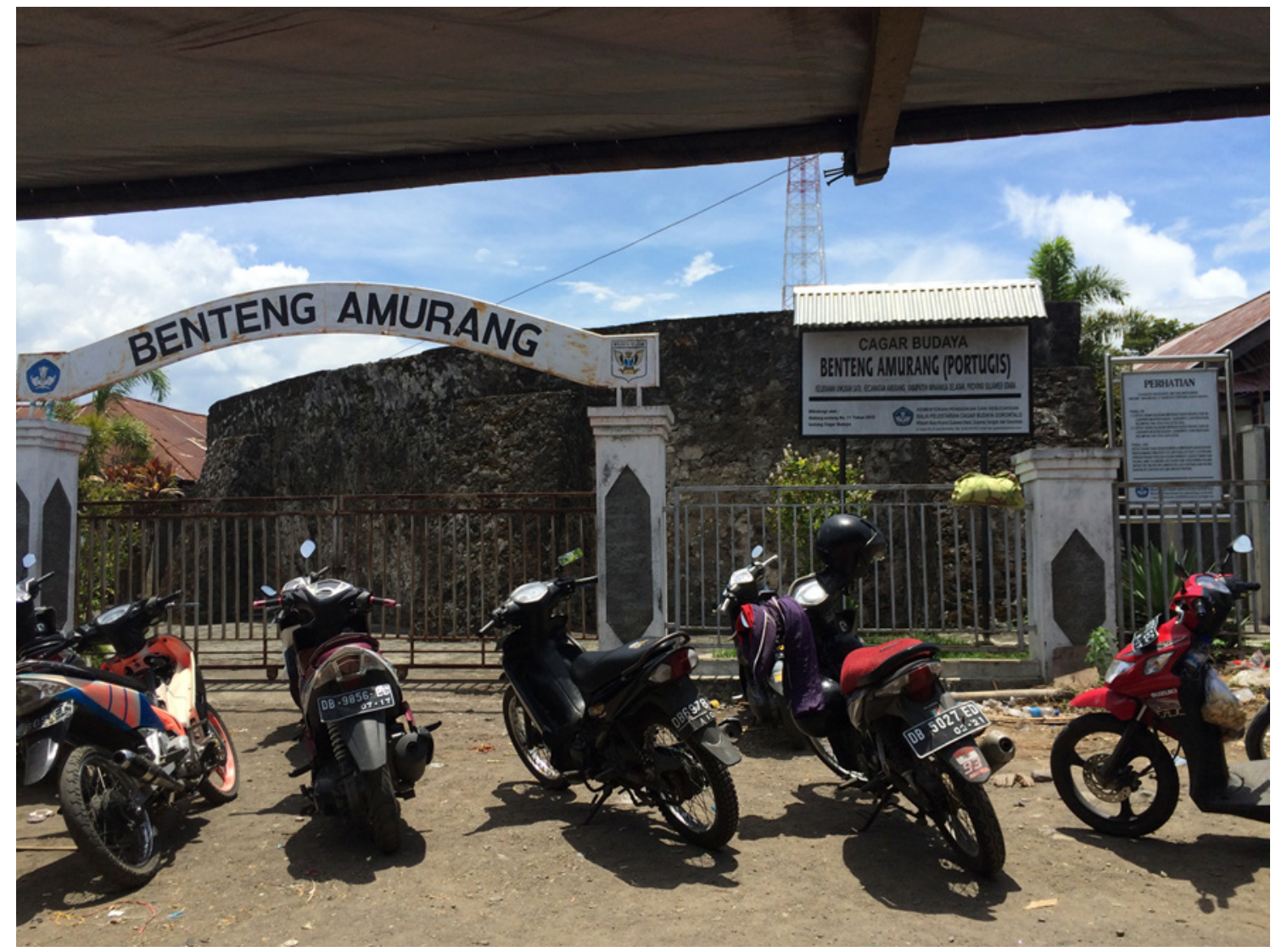

Source: Photo by Maria J.C. Schouten

Since those days, government bodies, in particular the district of South Minahasa as the owner of the premises, have taken measures to restore and protect the building. Now, a fence separates the fort complex from the street, and the gate is locked, which means that a visit can only be made with the co-operation of the juru pelihara, the caretaker. Inside the compound, part of the terrain is neatly covered with paving stones. There are well-kept stretches of lawn, and some shrubs, including the tawaan, a plant with a ritual connotation for Minahasans. Some lamp-posts have even been installed.

Above the entrance gate, a white-painted iron arch bears the inscription in capital letters 'Benteng Amurang' ('Fort Amurang'). The name is flanked by the coats of arms of, on the left side, the Ministry of Education and Culture, and on the other side, the kabupaten of South Minahasa. A large billboard announces that this is a Cultural Heritage Site, as specified under National Law 11 of 2010. On this billboard the name 
of the fortress is presented as 'Benteng Amurang (Portugis)', thereby combining the official name 'Benteng Amurang' with the common designation, 'Benteng Portugis' ('Portuguese Fort'). It is not clear whether this addition of 'Portugis' is intended to provide more information about its supposed origin, or to avoid possible misunderstandings. 'Benteng Portugis ${ }^{7}$ was the designation which, in elegant cast-iron letters, crowned the entrance to the terrain in the initial years of the millennium, when the first steps were being taken to rehabilitate and protect the fort. The fort's status of 'cultural heritage' makes the presence of yet another billboard mandatory, this one reminding the public of the caution and appropriate behaviour required in this area, referring to the principal articles of the law of 2010 (see figure 5).

The recent restoration of the fort was carried out mainly in conformity with the recommendations made by teams of archaeologists of the Balai Arkeologi Manado (Archaeological Office of Manado) who, since 1994, have been intermittently engaged in research whose purpose is to delineate the former lay-out of the fort and to ascertain its functions. More specifically, this research has attempted to determine the groundplan of the former fort, and to examine the possible existence of interior divisions and ancillary buildings. Another aim has been to determine the materials and the technology used in the building process. It was also hoped that the research would indicate the number of formerly existing bastions. In the architecture of forts in Europe and Asia from the sixteenth to the mid-nineteenth century, a bastion usually protruded from each of the corners of the outside ('curtain') wall ${ }^{8}$. In the case of Amurang, archaeologists quickly concluded that there had been no more than one bastion (Saptaningrum, 2000: 6). But questions still remained about the edifice into which this structure might have been integrated. Perhaps it was a complete building, roofed?

The research to discover possible other structures on this site is still ongoing. Not surprisingly, this investigation has been hampered by many factors. In the first place, the location in the bustling centre of a town where, down the ages, many houses and retail stalls have been built, demolished and rebuilt again. Consequently, material data shedding light on the history of the fort might be hidden below the adjacent buildings in which people now live and work. Not unnaturally, the fortress has suffered from the climate, the proliferation of lichen and the like, from military assaults from the

\footnotetext{
${ }^{7}$ Or rather 'Benteng Potugis', in spoken language.

${ }^{8}$ On the architecture of colonial forts, see for example Sarmento, 2011: 8.
} 
sea during the Pacific War, and from the use by the local population of the ready-made quarry for the construction of their own houses or roads. Despite these disadvantages, in the first phase of the research (in 1994) the archaeological team managed to make a preliminary estimate of the former terrain of the fort, on the basis of the remains of what they identified as being the old wall. Its area was then calculated at 165 x 105 metres, although this has not yet been definitively confirmed (see Fahriani, 1999/2000: 2-3; Saptaningrum, 2000: 18).

Figure 6: The fort in Amurang and its premises, viewed from above, at the occasion of the celebration of National Education Day, May 30, 2017. Top right (to the south of the fort): part of the marketplace.

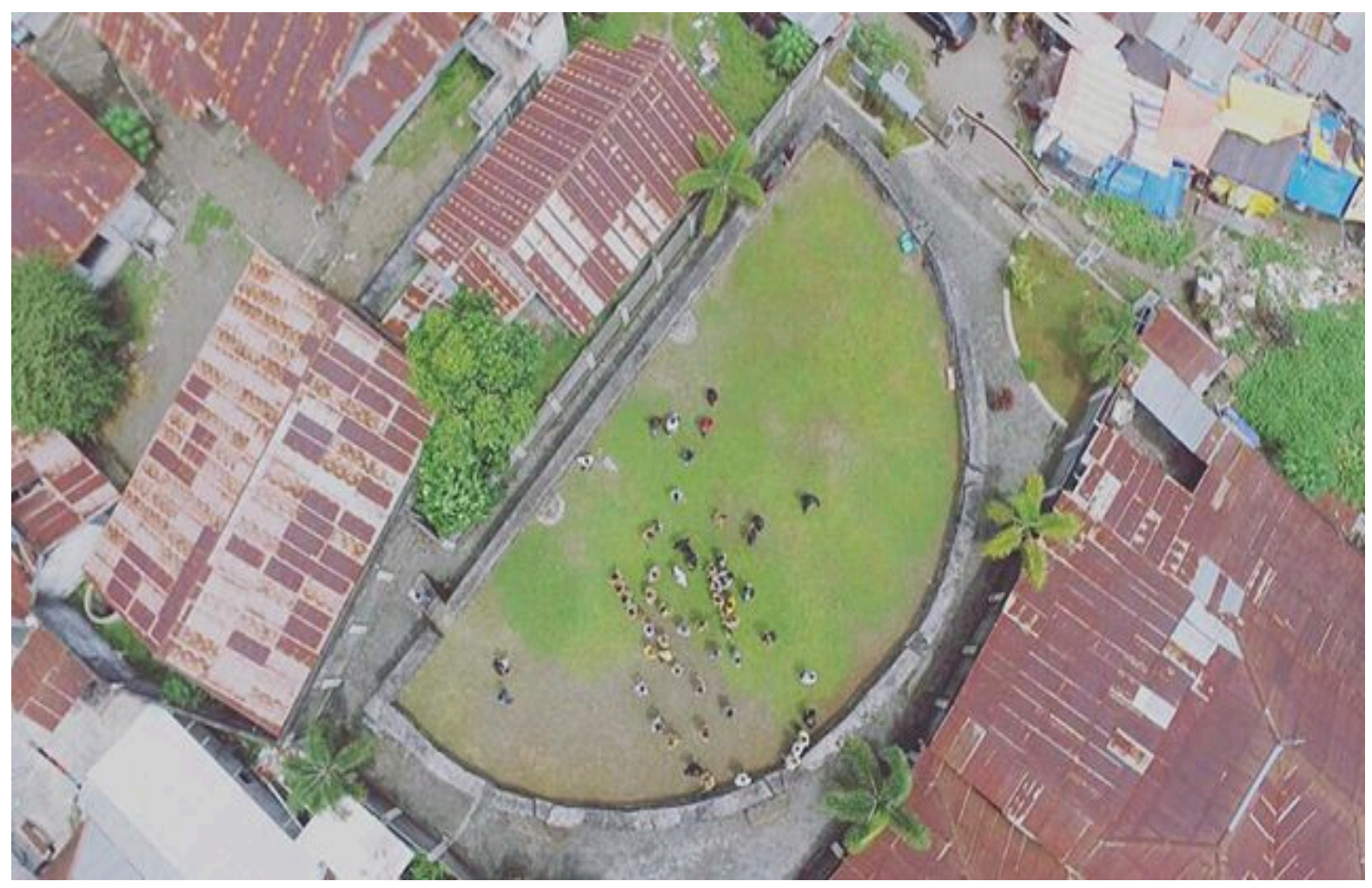

Photo by Felix Palenewen; courtesy the photographer.

The bastion's base, observed from above, has the shape of an almost perfect semi-circle, rather like the capital letter D (see figure 6). The curved part of this structure, that is the wall from which the cannons could be fired, faces the north-west, 
the sea, from where formerly the attackers could be expected. One reason advanced for the existence of just a single bastion is that, with few resources available, priority had to be given to a defence against this maritime peril, focusing on the entrance to the bay. However, the opposite side, the inland, also posed dangers, considering the reputation for ferocity of its 'Alfur' inhabitants.

The straight wall of the Amurang bastion, which might be envisioned as the diameter of the imaginary circle, extends for about 30 metres along the south-eastern side. In the centre of the wall is what seems like a door, measuring $2.30 \times 2.10 \mathrm{~m}$ and with a curved lintel. This door, and the doorpost, are made of the same material as the wall (although using smaller stones) and, at first sight, are scarcely distinguishable from it. As it is 'sealed' to the doorposts with cement, the door is unserviceable. At a point farther along the wall, a stairway consisting of eight steps leads to the top of the bastion, at a height of almost three metres. The platform is nowadays covered with grass, and the low walls show six indentations for the emplacement of cannons.

The research team has carried out several excavations to learn more about the internal structure of the fort-bastion ${ }^{9}$. The sites were selected with the assistance of some local people who were considered experts on local history, and who asserted, from hearsay in their youth, the existence of one or several subterranean tunnels leading to diverse locales in the town of Amurang. The door in the straight wall does seem to offer a clue. As it could not be opened, in the year 2000 the ground below this entrance was examined and an empty space was found behind the door, a circumstance which confirmed the existence of some cavities inside the bastion building. Unfortunately, danger from falling of stones and sand forced the team to suspend this first phase of the digging. It was then decided that an excavation from above, the roof of the bastion, should be begun. Again, the selection of the site was to some extent influenced by the suggestions and stories of the local population. The digging process from the top resulted in the discovery of a stone structure which might have been part of a staircase. However, the long-awaited disentangling of the mystery of the putative underground corridors, and of the sealed room or rooms, did not happen (Fahriani, 1999/2000: 13-14; Saptaningrum, 2000: 11-12). For the time being, no valid indications have been found to suggest either a possible former use of the spaces, or of a subterranean tunnel, graves,

\footnotetext{
${ }^{9}$ Information about these team processes were obtained through interviews in 2016 kindly granted by members of the Balai Arkeologi, and the examination of research reports.
} 
chests with gold, or a chapel - as some locals had indicated. In the course of the digging process, the team retrieved various artefacts like pieces of ceramics, ammunition and a coin from the VOC period (Saptaningrum, 2000: 16-17). None of this was special, and even the VOC coin was a common specimen.

The motives for the roofing of the inside area of the bastion are not clear, and the period in which this modification took place has, so far, not been established by the archaeological research. Locals state that the trigger was an eruption of Soputan, one of the major volcanoes in Minahasa. This might have been a motive, but it offers no clue about the date of the roofing construction, because Soputan has erupted on numerous occasions. One of the largest eruptions recorded took place in 1832, when, according to contemporary authors, the streets of Amurang were covered with a thick layer of mud, and the sediment was still noticeable in the 1840s (Graafland, 1898, 1:27, 88).

The material used for the construction, another theme in the archaeological research, consists of limestone and andesite mixed with coral, calcium, and sand from the neighbouring beach. According to the locals, to compound the mortar, the builders also made use of the egg whites of the maleo bird but, considering the absence of proper laboratory research, the archaeological team has been reticent about this claim (Saptaningrum, 2000: 21). That the maleo bird pops up in this local story is very probably attributable to its symbolic value for Minahasans and foreign visitors alike. It adds, almost literally, more flavour to the stories about the fort. It also provides a reason for the apparent absence of maleo birds in the region of Amurang. As is stated in a document produced by the Department of Culture, the Portuguese, the reputed builders of the fort, poached the maleo eggs with such ardour that the bird, formerly abundant, is now extinct in this coastal region (Gigir, 2014). This way, rather than pointing the finger at the poaching proclivities of their fellow-countrymen, Minahasans blame this impoverishment of their fauna on foreigners, the Portuguese.

The restoration of the fort was essentially the repair of the ruined upper part of the wall. Also, the building was cleaned and enclosed, the area immediately adjacent was landscaped, and the regional tourist and educational institutions have developed activities to promote this heritage site. Nowadays, the fort regularly welcomes visitors, usually in groups. They are given a guided tour by the caretaker, who uses a large personal notebook containing miscellaneous data to support his explanations. The stories he tells are a mixture of folk knowledge and information obtained from 
archaeologists and some amateur historians. The latter actually rely heavily but eclectically on historical studies conducted in the Dutch colonial period, which can be found in books and other publications ${ }^{10}$. In the narratives about the fort transmitted by the guide, the supposed Portuguese origins are emphasized. But, how 'Portuguese' was the fortress? We shall scrutinize this question in greater detail in the next section.

Portuguese?

The year of the foundation of Fort Amurang is as yet uncertain. So far the archaeological team has also been unable to determine it. Of the European powers once present in this part of the Asian world, in theory three could qualify as its builders or initiators: the Portuguese, the Spanish and the Dutch.

Contrary to the statements of the locals and the cultural and tourist authorities, the Portuguese have the slimmest chance of this trio. As said, the only documented expeditions to northern Sulawesi by the Portuguese, sailing from their base in Ternate, were the short missionary visits in the 1560 s. It is certainly possible that individual Portuguese, such as traders or deserting soldiers or seamen, did sojourn in Minahasa, but their influence on and interest in the area would have been slight and would have neither warranted nor enabled the building of a stone fort.

This notwithstanding, the notion that it was the Portuguese who built the bastion and resided in the fortress has taken strong root among the population. Features of the building itself prove to be a fertile ground for the blossoming of stories about the Portuguese. For instance, the presumed subterranean corridors are said to have led to the gravesites of Portuguese men. Moreover, the fact that the staircase on the bastion wall has only eight, quite high, steps, is attributed to the supposed extraordinarily tall stature of the builders of this staircase, the Portuguese. In addition, on top of the wall of the fort, there is a small stone elevation in which is inscribed ' 1512 '. Although it is unclear when this inscription was made, for locals and visitors alike it serves as definitive proof of a Portuguese origin of the fort. After all, 1512 was the year, as every Indonesian with

\footnotetext{
${ }^{10}$ In particular on the study by Godée Molsbergen (1928). Transcriptions of names from this and other publications show numerous errors.
} 
some schooling is supposed to know, in which the Portuguese sailed to Eastern Indonesia, as pioneers among the western powers ${ }^{11}$.

Indeed, the central themes of the nationally and regionally produced travel guides and Internet sites, as well as the information provided in loco, state that the Amurang fort dates from the beginning of the sixteenth century, and the year 1512 and the name of António de Abreu are often explicitly mentioned. Abreu was the commander of the first Portuguese expedition to Eastern Indonesia from Malacca, and he did reach the islands of Buru, Amboina, Ceram and Banda in early 1512, while there are no indications that he sailed farther to the north ${ }^{12}$. Rather, from the Central Moluccas, Abreu's fleet set sail for the return voyage to Malacca (Sollewijn Gelpke, 1995: 88; Ellen, 2003: 65).

Hence it is highly unlikely that the Portuguese were the initiators of the fort, and it seems much more probable that this honour can be claimed by the Spanish. We have already mentioned their influence in southern Minahasa for several decades of the seventeenth century, including recurring references in reports to a 'Spanish fort' on the Bay of Amurang. The third possibility, that the fort in the centre of Amurang was built by the VOC, cannot now be completely dismissed. However, we have no supporting material from written or oral history at our disposal, and so will now skip an analysis of the pros and cons of this scenario.

It has been stated above that the Spanish had more influence and stayed in Minahasa for a much longer time than the Portuguese with their few short visits. Notwithstanding, today the presence of the Spanish in Minahasa history is rarely referred, and local people seem only hazily aware of it. 'Habis portugis, nanti belanda' ('When the Portuguese left, the Dutch came') is what some Minahasans have stated in recent conversations. Hence, they omit the Spanish period, as far as the European powers which influenced Minahasa were concerned. Moreover, in conversations in the villages, it was discovered that many considered 'Spanish' and 'Portuguese' to refer to the same nation.

\footnotetext{
${ }^{11}$ In some of the books by the leading Indonesian artist Remy Sylado, whose family hails from Amurang, the year 1512 has also an important place, marking the first contacts between Minahasans and Portuguese. The same applies to the widely read book by Kowaas (2010).

${ }^{12}$ In truth, after an accidental detour marred by a shipwreck and delays, Francisco Serrão, the second commander of Abreu's fleet, did land with his craft on the more northerly situated Ternate, but he then remained there until his death in 1521 (Andaya 1993: 115).
} 
Not surprisingly, emic viewpoints about the former presence of European powers in Minahasa before the VOC have not always been the same. The Dutch colonial civil servant cum ethnographer J.G.F. Riedel indicated in the 1860 s that Minahasans, while not referring to the Portuguese in their account of history, declared that the 'Tasikela' (Castilians, hence Spanish) were the first westerners to arrive (Riedel, 1869: 514). It is recorded that the area south of the Rano i Apo river was an important provider of rice for the Spanish, and that these had a small fortification on the coast, in the village of Kawangko'an Bawah, of which today only traces of the foundations are visible. In several southern villages remarkable blocks of trachyte are found, and the local population was, and today still is, convinced that it was on the initiative of the Spanish that these blocks were tooled, giving them a shape similar to that of rice mortars (De Clercq 1870: 534; Graafland, 1898, 2: 11; De Clercq, 1869). Memories of the Spanish were apparently alive in the nineteenth century, but faded later and the Portuguese have mostly taken the place of the Spanish in the collective imagination.

It is hard to find an overarching reason for the attribution of the epithet 'Portuguese' to the Amurang fort. But minor motives abound, such as the prestige Minahasans seem to derive from a history in some way associated with the Portuguese (see Schouten, 2016), although this predilection for the Portuguese will not attain the intensity of what has been called 'Lusomania'13. Factors to be considered are also the more important place attributed to the Portuguese in the history curriculum in Indonesian schools, and the influence of the information disseminated by the authorities and mass media.

Moreover, the erroneous attribution of a Portuguese origin to forts is a practice not unique to Minahasa. It happens elsewhere in northern Sulawesi, such as with the fort of Otanaha near the city of Gorontalo; it happens with Fort Den Briel on the island of Obi, and with the stronghold originally named Fort Nassau on Bandaneira (Indonesia Tourism, 2017; Van Goor and Van Goor, 2004: 49). It even occurs on the spice island of Ternate, whose history is well documented and studied and which is visited by many Indonesian and international travellers interested in culture and history ${ }^{14}$.

\footnotetext{
${ }^{13}$ This term is used by, for example, O'Neill (2006) in relation to the so-called Portuguese of Malacca.

${ }^{14}$ As the Portuguese historian Manuel Lobato (2009: 16) declares, after examining the forts in Ternate:

'... Much of what passes as cultural and touristic information is still in need of confirmation. Crucial
} 
Indonesians seem to apply the adjective 'Portuguese' to many old objects of apparently foreign origin that are considered to be 'very old'. When using this term, they are not always thinking of the Portuguese nation, or the Portuguese sailors, soldiers and traders who played a role in the history of Indonesia, but when they are, the term has positive connotations. Nonetheless, Indonesians have good reason to consider it a negative label, associated with colonization and extortion. In the spice islands or Moluccas, not far from Minahasa, the intentions and practices of the Portuguese (and Spanish) in the sixteenth and early seventeenth centuries were far from peaceful and generous, although some people may consider their evangelization efforts an exception. These early beginnings of colonialism were continued heavy-handedly by the Dutch, who gradually expanded their colonial rule over the huge archipelago known today as Indonesia $^{15}$.

Remarkable, moreover, is the positive attitude among present-day Minahasans and their neighbours in relation to the year ' 1512 ', the year of the arrival of the Portuguese in the Moluccas. This contrasts with the mixed feelings, in particular among the respective original population groups, about the year 1492 in the Americas, about 1498 in India, and about 1500 in Brazil. Opponents of festive commemorations of the so-called discovery of these areas or sea routes denounce the great disruption and exploitation generated by these first encounters between European nations and the other societies. On a more general level, they identify those historical dates with the beginning of the imposition of the cultural, political and economic hegemony of the Europeans over other nations. This is quite different from the magical meaning which 1512 usually has in Amurang and other parts of Indonesia.

In some very rare cases, less positive aspects of Portuguese activity in Eastern Indonesia are exposed. A case in point is an impressive monument on the island of Ternate, where the Portuguese occupied a powerful position for more than four decades in the sixteenth century. The massive column, recently inaugurated, evokes the history of tense relations between the Portuguese and the Sultans of Ternate, culminating in the murder of Sultan Hairun by the Portuguese in 1570, and followed five years later by the expulsion of the Portuguese. The carvings on the monument recount several episodes of

problems still have to be solved regarding the identification of each of the forts in Ternate.' See also Lobato, 2012.

${ }^{15}$ For colonial rule in Minahasa, see Henley, 1996; Schouten, 1998. Images and ideas about the Dutch are ambivalent in present-day Indonesia. But that is a different story. 
this story, depicting the Portuguese as either cruel or cowardly men, in contrast to the noble Ternatans. It is, however, ironic that on the same small island as this monument, celebrating the triumph of Ternate over the Portuguese, the authorities proudly exhibit the five or six buildings, and many other objects, that cultural and tourist organizations advertise as being 'Portuguese'. This is one of many cases of the co-existence of what Bissell (2005: 216) refers to as 'multiple strands of remembrance', which we also find in and around Amurang.

Figure 7: Monument in Ternate, celebrating the expulsion of the Portuguese (left) by the Ternatans (right).

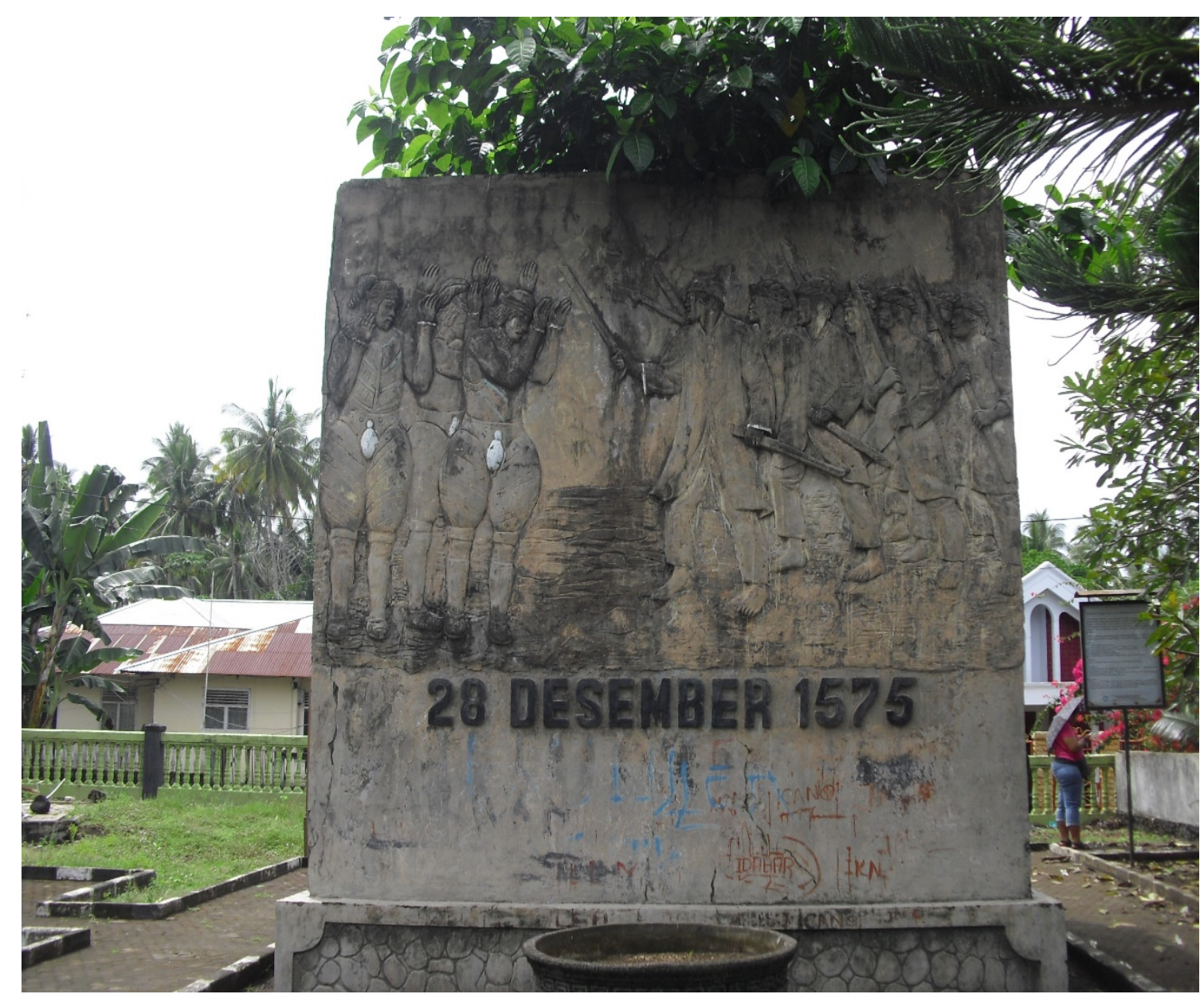

Photo by Maria J.C. Schouten 
Concluding remarks

Being a specific place that reminds a community of their common heritage, the fortification in Amurang is a lieu de mémoire (Nora, 1989), associated with a presumed former Portuguese presence in the region. For the population, this solid and attractive stronghold is proof of the long-standing importance of their town as a port and a trade hub. No matter how many times historical facts have been invented, forgotten, reinvented or adapted, the fort is a site for cherishing good memories. The recent restoration of the building and its immediate surroundings has reinforced this symbolic function. The fort has become more visible, and the accessibility of the site has been improved, permitting the admission of large groups of visitors. Today, the bastion, and in particular its roof, is occasionally used for official ceremonies. The attention which government departments and cultural or tourist entities have drawn to the heritage site, using social media, has contributed to a vast increase in visitor numbers. Thus, the economic function of the buildings and their associated histories or myths has also increased, in a process of commodification of the past of Amurang.

The archaeological investigation carried out during the restoration process has not yielded the spectacular outcome that was hoped for. Nevertheless, it has provided further insight into the construction process and layout of the building. In addition to their own expertise and knowledge, the archaeological team called upon the testimonies and narratives of the people living in the vicinity of the fort. To date, such folk memory has rarely been helpful in guiding archaeological enquiry. From the viewpoint of cultural anthropology, however, these narratives have great value and should be the subject of further research. The themes of some of these accounts are similar to those of (appropriately called) urban myths elsewhere in the world, such as the assumption about subterranean corridors, which may contain treasures and human remains. Another, more unique story offers a rare negative view of the Portuguese, blaming them for the nearextinction of the maleo-bird. This rather mild accusation, however, mainly appears to be a question of 'passing the blame', and may be a recent addition, serving to embellish accounts given to tourists, and to stress the connection between the fort and one of the icons of Minahasa, the maleo.

Some of the stories that over the years have been woven around the Amurang fort have recently become widespread, and have now come to be officially in the 
book': in the texts spread by government and cultural authorities, in school books, in the textbook of the guide, and the virtual book of the Internet. The existence of profound scientific studies on Indonesian history is in these cases often overlooked. Therefore, for instance, the name 'Portuguese fort' and the associated folk explanations cannot easily be erased from these 'new books', nor from the marketing material or the propaganda speeches of politicians. As it seems, the results of scientific research, the 'history', will live in parallel with 'memory', the accounts popular among the Minahasans.

\section{REFERÊNCIAS}

ANDAYA, Leonard Y. The world of Maluku: Eastern Indonesia in the early modern period. Honolulu, University of Hawaii Press, 1993.

BECCALONI, George \& PURSER, Simon. Impressive New Monument to Alfred Russel Wallace in Sulawesi, Indonesia, at The Alfred Russel Wallace Website, available at wallacefund.info/content/impressive-new-monument-alfred-russel-wallace-sulawesiindonesia. 2019.

BISSELL, William, Engaging colonial nostalgia, Cultural Anthropology. Vol. 20, n. 2, 2005, pp. 215-248.

DE CLERCQ, Frederik S.A. Sporen van het verblijf der Spanjaarden in de Minahasa. Tijdschrift voor Nederlandsch-Indië. Vol. 3, n. 2, 1869, pp. 415-416.

DE CLERCQ, Frederik S.A. De overzijde der Ranojapo, Tijdschrift voor Indische Taal-, Land- en Volkenkunde. Vol. 19, 1870, pp. 521-539.

DEKKER, René W. R. J. \&. MCGOWAN, Philip J.K. Megapodes: An Action Plan for Their Conservation 1995-1999. N.p, International Union for Conservation of Nature, 1995. ELLEN, Roy F., On the Edge of the Banda Zone: Past and Present in the Social Organization of a Moluccan Trading Network. Honolulu, University of Hawaii Press, 2003.

EVANS-PRITCHARD, Edward E., Anthropology and History, in Essays in social anthropology. Glencoe, IL., Free Press of Glencoe, 1963, pp. 46-64. [1951.]

FAHRIANI, Ipak. Laporan Penelitian arkeologi - Situs Benteng Amurang, kecamatan Tombasian, kabupaten Mianahasa, propinsi Sulawesi Utara. Manado, Departemen Pendidikan Nasional. Pusat Arkeologi. Balai Arkeologi Manado, 1999/2000

GIGIR, Krestian. Benteng Portugis (1512) - Amurang - Kabupaten Minahasa Selatan. Available at: http://krestiangigir.blogspot.pt/2014/10/benteng-portugis-1512-amurangkabupaten.html. 2014. 2014. Last access on May, 20, 2017.

GODÉE MOLSBERGEN, Everhardus C. Geschiedenis van de Minahassa tot 1829. Weltevreden, Landsdrukkerij, 1928.

GRAAFLAND, Nicolaas. De Minahassa. Haar verleden en haar tegenwoordige toestand. Volume 1. Rotterdam, Wijt, 1867.

GRAAFLAND, Nicolaas. De Minahassa. Haar verleden en haar tegenwoordige toestand. 2 volumes. (2nd edition). Batavia, Kolff, 1898.

HENLEY, David E.F., Nationalism and Regionalism in a Colonial Context: Minahasa in the Dutch East Indies, Leiden, KITLV Press, 1996. 
Indonesia Tourism. Otanaha Fortress. Available at: www.indonesiatourism.com/gorontalo/otanaha fortress.html. 2017. Last access on March, 24, 2019.

KOWAAS, Cornelis. Dewa Ruci: pelayaran pertama menaklukkan tujuh samudra : sebuah kisah nyata. Jakarta, Penerbit Buku Kompas, 2010.

LACH, Donald F. Asia in the Making of Europe, Volume I: The Century of Discovery. Chicago, University of Chicago Press, 2008.

LAPIAN, Adrian B. Orang laut, bajak laut, raja laut. Sejarah kawasan Laut Sulawesi abad ke XIX. PhD thesis, Universitas Indonesia, Jakarta, 1987.

LAPIAN, Adrian B. Laut Sulawesi: The Celebes Sea, from center to peripheries. Moussons vol. 7, 2004, pp. 3-16.

LOBATO, Manuel. Fortificações portuguesas e espanholas na Indonésia oriental. Lisboa, Prefácio, 2009.

LOBATO, Manuel. From European-Asian conflict to cultural heritage: identification of Portuguese and Spanish forts on Ternate and Tidore islands, in: JARNAGIN, Laura (ed.), Portuguese and Luso-Asian Legacies in Southeast Asia, 1511-2011, Volume 2, Singapore, Institute of Southeast Asian Studies. 2012. Pp. 179-207.

NORA, Pierre. Between memory and history: les lieux de mémoire. Representations, vol. 26, 1989, pp. 7-24.

O’NEILL, Brian J. Patrimónios sobrepostos: A Lusomania entre os Kristang de Malaca. In: Ramos, Manuel (ed.), A matéria do património: memórias e identidades. Lisboa, Colibri, 2003. Pp. 33-38.

PIRES, Ema C. Paraísos Desfocados. Nostalgia Empacotada e Conexões coloniais em Malaca. Tese de doutoramento em Antropologia Cultural, Lisboa, ISCTE-IUL. 2012.

PIRES, Ema C. Re-scripting colonial heritage. Cultura. International Journal of Philosophy of Culture and Axiology vol. 11, 2, 2014, pp. 129-139.

RIEDEL, Johann G.F. Het oppergezag der vorsten van Bolaang over de Minahasa (Bijdrage tot de kennis der oude geschiedenis van Noord-Selebes). Tijdschrift voor Indische Land- en Volkenkunde 17, 1869, pp. 505-524.

SAPTANINGRUM, Irna Laporan penelitian arkeologi. Studi arsitektural Benteng Amurang di Kecamatan Tombasian, Kabupaten Minahasa, propinsi Sulawesi Utara (Tahap IV). Manado, Departemen Pendidikan Nasional. Pusat Arkeologi. Balai Arkeologi Manado, 2000.

SARMENTO, João. Fortifications, post-colonialism and power. Ruins and imperial legacies. Londres, Ashgate, 2011.

SARMENTO, João. Paisagem e memória em São Tomé e Príncipe: o Forte de São Sebastião e Fernão Dias. Actas do Colóquio Internacional São Tomé e Príncipe numa perspectiva interdisciplinar, diacrónica e sincrónica (2012). Lisboa, 2012. Pp. 305-315.

SCHOUTEN, Maria J.C. Leadership and social mobility in a Southeast Asian society: Minahasa, 1677-1983. Leiden, KITLV Press, 1998.

SCHOUTEN, Maria J. Quelques communautés intermédiaires en Insulinde Orientale. In: Loureiro, Rui \& Gruzinski, S. (eds.), Passar as Fronteiras, II Colóquio Internacional sobre Mediadores Culturais - Séculos XV a XVIII. Lagos, Centro de Estudos Gil Eanes, 1999, pp. 245-264.

SCHOUTEN, Maria J.C. Património enigmático: os Portugueses na memória coletiva na Minahasa. Veritas, Díli vol. 4, n. 3, 2016, pp. 11-28.

SEVERIN, Tim. The Spice Islands Voyage. In Search of Wallace. London, Little, Brown and Company, 1997.

SOLLEWIJN GELPKE, J.H.F. Afonso d'Albuquerque's Pre-Portuguese Javanese map, partially reconstructed from Francisco Rodrigues' Book. Bijdragen tot de Taal-, Land- en 
Volkenkunde, Leiden, vol. 151, n. 1, 1995, pp. 76-99.

STOKMAN, Sigfridus. De Missies der Minderbroeders op de Molukken, Celebes en Sangihe in de XVIe en XVIIe eeuw. Collectanea Franciscana Neerlandica 'sHertogenbosch, vol. 2, 1931, pp. 499-556.

SURJANTO, Diman \& UMAR, Dwi Yani Yuniawati. Laporan Penelitian Arkeologi Ilsam do Kotamadya Manado dan sekitarnya Sulawesi Utara. Manado, Pusat Penelitian Arkeologi Nasional. Balai Arkeologi Manado, 1996.

VAN AERNSBERGEN, Antonius J. De Katholieke Kerk en hare missie in de Minahasa. Bijdragen tot de Taal-, Land-en Volkenkunde vol. 81, n. 1, 1925, pp. 8-60.

VAN GOOR, Jurrien \& VAN GOOR, Foskelien. Prelude to Colonialism: The Dutch in Asia. Hilversum, Verloren, 2004.

WALLACE, Alfred R. The Malay Archipelago. The land of the orang-utan and the bird of paradise. A narrative of travel, with studies of man and nature. New York, Dover Publications, 1962. [1869.]

WARREN, James. The Sulu zone 1768-1898. Singapore, Singapore University Press, 1981.

WATUSEKE, Frans S.W. \& HENLEY, David E.F. C.C. Predigers Verhandeling over het plaatselijke bestuur en de huishouding van de Minahasa in 1804. Bijdragen tot de Taal-, Land-en Volkenkunde vol. 150, n. 2, 1994, pp. 357-385.

YOUNG, Robert J.C. Postcolonialism: a very short introduction. Oxford, Oxford University Press. 2003.

Recebido 01/07/2019

Aprovado 24/07/2019 